IIUM

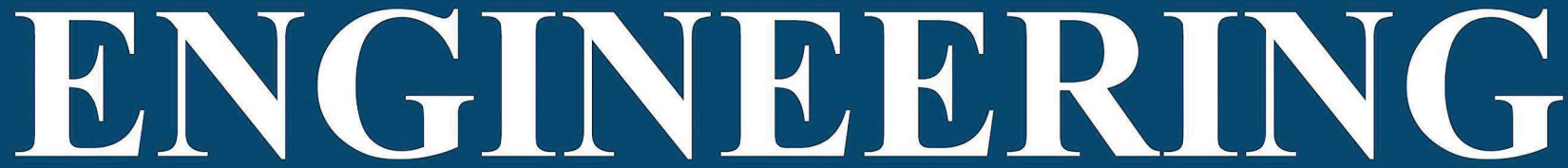

JOURNAL

Volume 23

Number 1

January 2022

\title{
INTERNATIONAL ISLAMIC UNIVERSITY MALAYSIA
}

ISSN: 1511-788X E-ISSN: 2289-7860

http://journals.iium.edu.my/ejournal 


\section{CHIEF EDITOR}

Ahmad Faris Ismail, IIUM, Malaysia

TECHNICAL EDITOR

Sany Izan Ihsan, IIUM, Malaysia

EXECUTIVE EDITOR

AHM Zahirul Alam, IIUM, Malaysia

ASSOCIATE EDITOR

Nor Farahidah Za'bah, IIUM, Malaysia

LANGUAGE EDITOR

Lynn Mason, Malaysia

COPY EDITOR

Hamzah Mohd. Salleh, IIUM, Malaysia

MALAY TRANSLATOR

Nurul Arfah Che Mustapha, IIUM, Malaysia

\section{EDITORIAL BOARD MEMBERS}

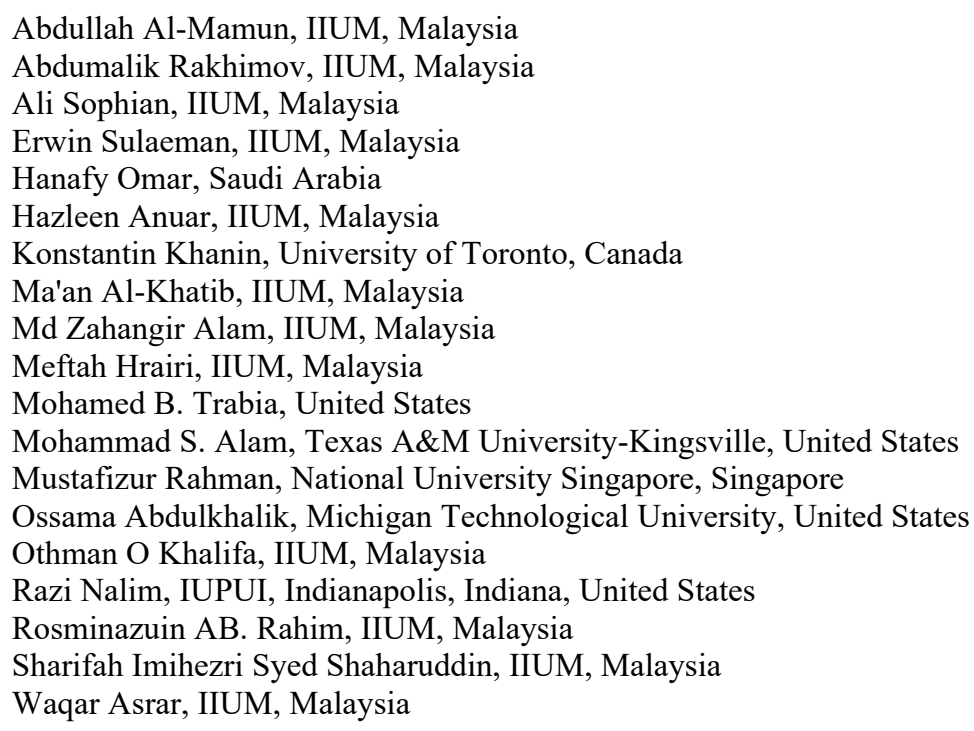

\section{AIMS \& SCOPE OF IIUMENGINEERING JOURNAL}

The IIUM Engineering Journal, published biannually (January and July), is a carefully refereed international publication of International Islamic University Malaysia (IIUM). Contributions of high technical merit within the span of engineering disciplines; covering the main areas of engineering: Electrical and Computer Engineering; Mechanical and Manufacturing Engineering; Automation and Mechatronics Engineering; Material and Chemical Engineering; Environmental and Civil Engineering; Biotechnology and Bioengineering; Engineering Mathematics and Physics; and Computer Science and Information Technology are considered for publication in this journal. Contributions from other areas of Engineering and Applied Science are also welcomed. The IIUM Engineering Journal publishes contributions under Regular papers and Invited review papers. It also welcomes contributions that address solutions to the specific challenges of the developing world and address science and technology issues from an Islamic and multidisciplinary perspective.

\section{REFEREES' NETWORK}

All papers submitted to IIUM Engineering Journal will be subjected to a rigorous reviewing process through a worldwide network of specialized and competent referees. Each accepted paper should have at least two positive referees' assessments.

\section{SUBMISSION OF A MANUSCRIPT}

A manuscript should be submitted online to the IIUM-Engineering Journal website at http://journals.iium.edu.my/ejournal. Further correspondence on the status of the paper could be done through the journal website. 


\title{
INTERNATIONAL ADVISORY COMMITTEE
}

\author{
A. Anwar, United States \\ Abdul Latif Bin Ahmad, Malaysia \\ Farzad Ismail, USM, Pulau Pinang, Malaysia \\ Hanafy Omar, Saudi Arabia \\ Hany Ammar, United States \\ Idris Mohammed Bugaje, Nigeria \\ K.B. Ramachandran, India \\ Kunzu Abdella, Canada \\ Luis Le Moyne, ISAT, University of Burgundy, France \\ M Mujtaba, United Kingdom \\ Mohamed AI-Rubei, Ireland \\ Mohamed B Trabia, United States \\ Syed Kamrul Islam, United States \\ Tibor Czigany, Budapest University of Technology and Economics, Hungary \\ Yiu-Wing Mai, The University of Sydney, Australia.
}

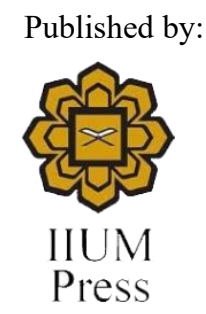

IIUM Press,

International Islamic University Malaysia

Jalan Gombak, 53100 Kuala Lumpur, Malaysia

Phone (+603) 6421-5014, Fax: (+603) 6421-6298

Whilst every effort is made by the publisher and editorial board to see that no inaccurate or misleading data, opinion or statement appear in this journal, they wish to make it clear that the data and opinions appearing in the articles and advertisement herein are the responsibility of the contributor or advertiser concerned. Accordingly, the publisher and the editorial committee accept no liability whatsoever for the consequence of any such inaccurate or misleading data, opinion or statement.

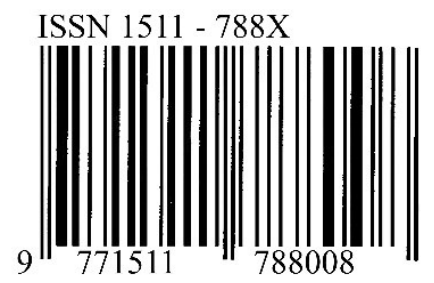

IIUM Engineering Journal

ISSN: 1511-788X E-ISSN: 2289-7860 


\title{
IIUM ENGINEERING JOURNAL
}

\author{
Volume 23, Issue 1, January 2022 \\ https:/doi.org/10.31436/iiumej.v23i1 \\ Table of Contents
}

EDITORIAL

\section{CIVIL AND ENVIRONMENTAL ENGINEERING}

1781: CONSOLIDATION INTEGRATED BUOYANCY EQUATION FOR SOFT GROUND IMPROVED WITH

Lightweight PolyURETHANE FoAM. . .1

Diana Che Lat, Ismacahyadi Bagus Mohamed Jais, Nazri Ali, Nor Zurairahetty Mohd Yunus,

Nor Hibatul Wafi Nor Zarin and Atiqah Najwa Zainuddin

1788: Potential Volumizing EFFECT OF THE Post-MorPh Lime FiLleR IN ATTENUATING ConCRETE

CARBONATION

Muhamad Hasif Hussin, Mohd Haziman Wan Ibrahim, Nor Hazurina Othman, Mohammed Yahya

Mohammed Al-Fasih and Mohd Fadzil Arshad

2119: CRITICAL SuCCESS FACTORS FOR BIM IMPLEMENTATION FOR POWER Plant PROJECTS IN MALAYSIA

Mohd Azrul Aziz, Chee Fui Wong, Nuzul Azam Haron, Aidi Hizami Ales, Raja Ahmad Azmeer Raja Ahmad Effendi and Ooi Kuan Tan

\section{ELECTRICAL, COMPUTER AND COMMUNICATIONS ENGINEERING}

1663: PERFormance ANALYSIS ON DYNAMIC WIRELESS CHARGING FOR ELECTRIC VEHICLE USING FERRITE CORE

Siti Hajar Yusoff, Amira Aziera Abdullah, Nadia Nazieha Nanda and Ahmed Samir Abed Badawi

1744: DESIGN AND ANALYSIS OF A MiCROSTRIP PATCH ANTENNA AT 7.5 GHz FOR X-BAND VSAT

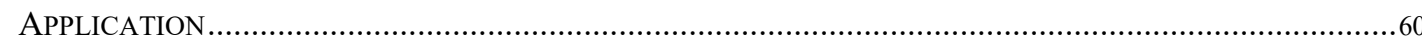

Sarah Yasmin Mohamad, Noralya Fatin Muzamil, Norun Farihah Abdul Malek, S.M.A. Motakabber, Rafidah Abd Malik and Nurain Izzati Shuhaimi

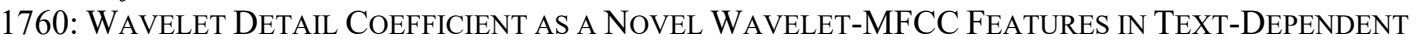
SPEAKER RECOGNITION SYSTEM.

Syahroni Hidayat, Muhammad Tajuddin, Siti Agrippina Alodia Yusuf, Jihadil Qudsi and

Nenet Natasudian Jaya

1783: IN-IDRIS: MODIFICATION OF IDRIS STEMMING ALGORITHM FOR INDONESIAN TEXT .82 Febiarty Wulan Suci, Nur Hayatin and Yuda Munarko

1789: BOTNET DETECTION USING INDEPENDENT COMPONENT ANALYSIS .VI Wan Nur Hidayah Ibrahim, Ali Selamat and Ondre Krejcar

1802: Color IMAGE RETRIEVAL BASED ON FUZZY NEURAL NETWORKS AND SWARM INTELLIGENCE VI Baydaa Ibraheem Khaleel

1803: ENHANCEMENT OF STABILITY ON AUTONOMOUS WAYPOINT MisSION OF QUADROTOR USING LQR INTEGRATOR CONTROL

Oktaf Agni Dhewa, Tri Kuntoro Priyambodo, Aris Nasuha and Yasir Mohd Mustafah

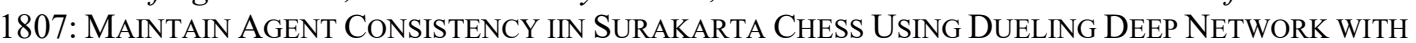
INCREASING BATCH.

Rian Adam Rajagede

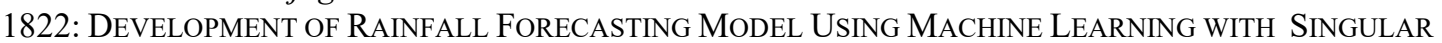
SPECTRUM ANALYSIS Pundru Chandra Shaker Reddy, Yadala Sucharitha and Goddumarri Surya Narayana

1825: ClASSIFICATION MODEL FOR BREAST CANCER MAMMOGRAMS .VII Suzani Mohamad Samuri, Try Viananda Nova, Bahbibi Rahmatullah, Wang Shir Li and Z.T. Al-Qaysi

2053: An IMMERSIVE AugMENTEd REALITY SyStem to STUdy THE EFFICIENCY OF DyNAMIC EXIT SIGNAGE VII Azhar Mohd Ibrahim, Muhammad Arif Kamaruddin andAzni Nabela Wahid

2086: COMPUTATIONLESS PALM-PRINT VERIFICATION USING WAVELET ORIENTED ZERO-CROSSING SIGNATURE. VII Jitendra Prabhakar Chaudhari, Hiren Kantilal Mewada, Amit Vinubhai Patel, Keyur Kamaldasji Mahant and Alpesh Dudabhai Vala 
2115: A Study Of Channel And Delay-BASed Scheduling Algorithms For LiVE Video StREAMING IN THE FIFTH GENERATION LONG TERM EVOLUTION-ADVANCED NETWORK ................................... VII Liza Abdul Latiff, Huda Adibah Mohd Ramli, Ani Liza Asnawi and Nur Haliza AbdulWahab

2135: Detection TrafFic Density with Image Processing Using Pin Hole Algorithm .................... VII Mochamad Aditya Irawanto, Casi Setianingsih and Budhi Irawan

\section{MATERIALS AND MANUFACTURING ENGINEERING}

1620: BIODEGRADATION OF MANGO SEED STARCH FILMS IN SOIL .VII Nur'Aishah Ahmad Shahrim, Norshahida Sarifuddin, Ahmad Zahirani Ahmad Azhar and Hafizah Hanim Mohd Zaki

1693: EXPERIMENTAL INVESTIGATION OF THE INFLUENCE OF MULTI-RECYCLING ON THE FRACTURE BeHAVior of Post CONSUMER High IMPACT Polystyrene From DisPosABle CuPs EVALUATED By THE J-INTEGRAL APPROACH..... .VII Hanan El Bhilat, Hassan Mabchour, Houda Salmi, Abdelilah Hachim and Khalid El Had

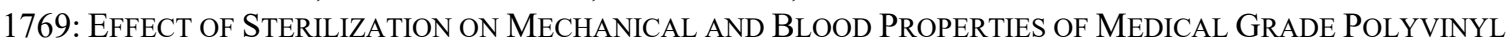
CHLORIDE.

Maryam Poostchi and Hamed Bagheri

1816: Magnetically Modified SugarCANe Bagasse Disordered CARBON AS a CADMIUM REMOVAL AGENT IN WATER Izzaty Syahirah Baharudin, Noraini Mohamed Noor, Ezzat Chan Abdullah, Raihan Othman and Mubarak Nasibab Mujawar

1842: APPliCATION OF House of QuAlity In THE CONCEPTUAl DESIGN OF BATIK WAX EXTRUdER AND PRINTER Nurul Anissa Mohd Asri, Abdul Malek Abdul Hamid, Norhashimah Shaffiar, Nor Aiman Sukindar, Sharifah Imihezri Syed Shaharuddin and Farid Syazwan Hassan

1848: MECHANICAL CHARACTERIZATION OF POLYESTER/ E-GLASS FIBER REINFORCED/MWCNTs NANOCOMPOSITES Naguib G. Yakoub

2114: EVALUATION OF SURFACE ROUGHNESS AND MATERIAL REMOVAL RATE IN ELECTRICAL DISCHARGE MACHINING OF AL-ALLOY WITH 10\%SIC Abbas Fadhil Ibrahim

2031: INFLUENCE OF IPNS (VINYLESTER / EPOXY / POLYURETHANE) ON THE MECHANICAL PROPERTIES OF GLASS / CARBON HYBRID COMPOSITES .... ..VIII Karjala Santhosh Priya, Kuttynadar Rajammal Vijaya Kumar, Gopi Suresh, Rajesh Ravi, Chockalingam Devanathan and Chinathambi Muthukaruppan Meenakshi

\section{MECHANICAL AND AEROSPACE ENGINEERING}

1804: Flow Induced Vibration In SQuARe Cylinder of VARIOUS ANGLES OF ATtACK. .VIII Nur Ain Shafiza Ramzi, Lee Kee Quen, Nur Amira Balqis Mohd Zainuri, Hooi-Siang Kang, Nor'Azizi Othman and Keng Yinn Wong

1812: Vehicle Air Conditioner (VAC) Control System Based on Passenger Comfort: A Proof of CONCEPT

Suroto Munahar, Bagiyo Condro Purnomo, Muhammad Izzudin, Muji Setiyo and Madihah Mohd Saudi

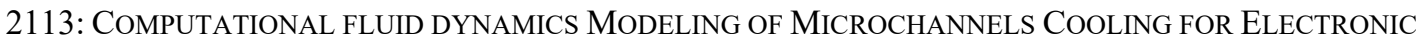
MICRODEVICES. Jonathan Fábregas, Henry Santamaría, Edgardo Buelvas, Saul Pérez, Carlos Díaz, Javier Carpintero, Ricardo Mendoza and Jennifer Villa

2138: COMPARATIVE STUdY ON DEGRADATION OF POLYLACTIC ACID/ SYZYGIUM AROMATICUM COMPOSITES AGEING IN OUTDOOR ENVIRONMENT AND SOIL BURIAL Salina Budin, Normariah Che Maideen, Koay Mei Hyie, Hamid Yussof and Halim Ghafar

2146: NuMERICAL Modelling OF BIRD STRIKE ON A RotATING ENGINE BLADES BASED ON VARIATIONS OF POROSITY DENSITY ..VIII Sharis-Shazzali Shahimi, Nur Azam Abdullah, Meftah Hrairi, Ameen Top and Ahmad Faris Ismail 


\section{MECHATRONICS AND AUTOMATION ENGINEERING}

1971: Optimal Piezoelectric Shunt Damper Using Enhanced Synthetic Inductor: Simulation AND EXPERIMENTAL VALIDATION

Muhamad Nazri Suhaimi, Azni Nabela Wahid, Norhidayati Diyana Nordin, and Khairul Affendy Md Nor

2156: MaXimizing Output Voltage of a Piezoelectric Energy Harvester Via Beam Deflection METHOD FOR LOW-FREQUENCY INPUTS ...VIII Mohamad Safiddin Mohd Tahir, Noor Hazrin Hany Mohamad Hanif and Azni Nabela Wahid 